\title{
Reproductive cycle of Mytella guyanensis (Lamarck, 1819) in a Marine Reserve (RESEX Bay of Iguape), Bahia, Brazil
}

\author{
V. M. A. Camilo, ${ }^{a, b *}$, J. da C. Souza ${ }^{b}$, E. de J. Conceiçãoo ${ }^{b}, J . R$. Luz $^{c, d}$, G. Boehs ${ }^{a, c}$ and \\ S. Campiolo ${ }^{a}$ \\ aPrograma de Pós-graduação em Desenvolvimento e Meio Ambiente, Universidade Estadual de Santa Cruz - UESC, \\ Rod. Ilhéus-Itabuna, Km 16, CEP 45652-900, Ilhéus, BA, Brazil \\ ${ }^{\text {b} C e n t r o ~ d e ~ C i e ̂ n c i a s ~ d a ~ S a u ́ d e, ~ U n i v e r s i d a d e ~ F e d e r a l ~ d o ~ R e c o ̂ n c a v o ~ d a ~ B a h i a ~-~ U F R B, ~ A v . ~ C a r l o s ~ A m a r a l, ~ 1015, ~}$ \\ Cajueiro, CEP 44570-000, Santo Antônio de Jesus, BA, Brazil \\ 'Programa de Pós-graduação em Ciência Animal, Universidade Estadual de Santa Cruz - UESC, Rod. Ilhéus-Itabuna, \\ Km 16, CEP 45652-900, Ilhéus, BA, Brazil \\ 'Instituto Federal de Educação, Ciência e Tecnologia Baiano - IF Baiano, Campus Uruçuca, Rua Dr. João Nascimento, \\ s/n, Centro, CEP 45680-000, Uruçuca, BA, Brazil \\ *e-mail: vcamilo@ufrb.edu.br
}

Received: April 23, 2016 - Accepted: October 10, 2016 - Distributed: May 31, 2018

(With 8 figures)

\begin{abstract}
Mytella guyanensis, consumed and commercialized in coastal regions of Brazil, is one of several bivalve species of socioeconomic interest for coastal communities. Besides serving as a source of income and subsistence for these communities, it also contributes to their food security as it is a source of proteins and micronutrients. Thus, the reproductive cycle of this species was studied aiming to contribute to food security and its preservation. Samples were collected monthly, between March 2014 and March 2015, in a natural stock (12 38'50'S; 38 51'43'W) in a Marine Reserve (RESEX Bay of Iguape) (community Engenho da Ponte), Bahia, Brazil. Mytella guyanensis is collected by women on site, where the artisanal fishing of this resource is performed without following any specific handling procedure. Also, empirical evidence indicates overexploitation. The specimens collected were measured along the anterior-posterior axis (length), and after macroscopic analysis they were fixed in Davidson solution, processed by routine histology techniques and stained with Harris haematoxylin and eosin (H\&E). The macroscopic analysis showed sexual dimorphism, with the male and female gonads presenting a milky-white and orange colour, respectively. A 1:1 sex ratio (M: F) was observed and reproduction of the species was continuous all year round. March, April, July and August were the months with highest values of gamete elimination. We suggest that a M. guyanensis management plan should restrict capture during these months, in order to sustainably regulate exploitation of this food resource in this reserve.
\end{abstract}

Keywords: bivalve, mytilidae, gametogenesis, environmental protection area.

\section{Ciclo reprodutivo de Mytella guyanensis (Lamarck, 1819) na Reserva Extrativista Marinha Baía do Iguape, Bahia, Brasil}

\begin{abstract}
Resumo
Mytella guyanensis, consumida e comercializada em regiões litorâneas do Brasil, é uma das diversas espécies de bivalves de interesse socioeconômico para comunidades litorâneas. Além de servir como fonte de renda e subsistência para essas comunidades, esta contribui para a sua segurança alimentar, por ser fonte de proteínas e micronutrientes. Assim, o ciclo reprodutivo desta espécie foi estudado visando contribuir com a segurança alimentar e a preservação da mesma. As amostragens foram realizadas mensalmente, entre março de 2014 e março de 2015 em um estoque natural (12³8'50"S e 38 51'43”W) na Reserva Extrativista Marinha Baía do Iguape (comunidade Engenho da Ponte), Bahia. Mytella guyanensis é coletada no local por mulheres, onde a pesca artesanal desse recurso é realizada sem seguir nenhum procedimento específico de manejo e evidência empírica indica sobrexplotação. Os espécimes coletados foram medidos ao longo do eixo ântero-posterior (comprimento) e após a análise macroscópica, foram fixados em solução de Davidson, processados por técnicas rotineiras de histologia e coradas em hematoxilina de Harris e eosina (HE). A análise macroscópica evidenciou dimorfismo sexual, com as gônadas de machos e fêmeas apresentando coloração branco leitosa e alaranjada, respectivamente. Uma proporção sexual (M: F) de 1:1 foi observada e a reprodução foi contínua ao longo do ano. Março, abril, julho e agosto apresentaram os maiores valores de eliminação de gametas. Sugerimos que um plano de manejo de M. guyanensis restrinja a captura deste durante esses meses, a fim de regular de forma sustentável a exploração desse recurso nesta reserva.
\end{abstract}

Palavras-chave: bivalve, mytilidae, gametogênese, área de proteção ambiental. 


\section{Introduction}

Studies on the reproductive biology of economically important aquatic species are essential to comprehend its life history (Garner et al., 1999) and are important in management actions. Studies supply information about the period of gamete release, sex ratio, and reproductive potential, subsidizing actions to maintain natural stocks and the preservation of the species (Araújo, 2001). According to Carranza et al. (2009) studies report declining stocks of bivalves across Brazilian's Northeast coast, mainly due to overexploitation and the loss of habitat of species.

The Mytilidae family (Mollusca: Bivalvia) includes various species with socioeconomic interest, being a source of income and livelihood for coastal communities (Nishida and Leonel, 1995; Carranza et al., 2009), which contributes to their food security, because they are sources of proteins as well as micronutrients, such as vitamin A, Iron, and Zinc (Santos et al., 2014). Furthermore, mussels may sometimes be the only affordable source of protein available. One of these species is Mytella guyanensis (Lamarck, 1819), popularly known as "bacucu", "bico de ouro", and "sururu" (Rios, 1994; Pinto and Boehs, 2008). This mytilid is distributed from Mexico to Peru, on the Pacific Ocean, and from Venezuela to Brazil, on the Atlantic (Rios, 2009), inhabiting intertidal regions of mangroves where it uses the byssus to attach to underground roots. It is euryhaline, i.e., it resists wide variation in salinity and is dioecious (Sibaja, 1986).

Although consumed and commercialized in Brazil's coastal regions, there are relatively few studies of its reproductive biology, namely: Grotta (1993) who described the species reproductive cycle in Paraíba; Christo and Absher (2001) in Paraná; Carpes-Paternoster (2003) in Santa Catarina; Adorno (2003) in Bahia's Recôncavo; Gomes et al. (2009) in Pará; and Luz (2009) in Ilhéus, south of Bahia.

The Reserva Extrativista Marinha Baía de Iguape (RESEX), a marine reserve, and as such to which is prioritized the sustained exploitation of resources within the limits that do not compromise environmental sustainability (Brasil, 2000), was created in August 11 ${ }^{\text {th }}$, 2000 , it has an area of 10.082.45 ha, and is located in the municipalities of Maragogipe and Cachoeira, in the region of Bahia's Recôncavo, located $111 \mathrm{~km}$ from the capital of the state of Bahia, Salvador. In the community Engenho da Ponte, north of the Reserve, women of the community collect $M$. guyanensis for sale and as food for their own families. However, in spite of being an area of environmental protection, the species is collected without any control by the local population, i.e., the artisanal fishing of this resource is done without following any specific handling procedure (Prost, 2010). Thus, empirical evidence demonstrates that the overexploitation combined with easily accessible natural stocks, are the main factors that affect this species in this Reserve.

Considering the economic importance represented by M. guyanensis for the communities from this RESEX, this study aimed to determine the reproductive cycle of the species in this marine reserve, with a view to contributing to food security of the communities living there, and to preserve it as a resource.

\section{Material and Methods}

Samples of M. guyanensis were collected from a natural stock from the RESEX Bay of Iguape at the coordinates $12^{\circ} 38^{\prime} 50^{\prime \prime} \mathrm{S}$ and $38^{\circ} 51^{\prime} 43^{\prime \prime} \mathrm{W}$, in the community Engenho da Ponte, Cachoeira, Bahia, Brazil. Every month, between March 2014 and March 2015, 30 adult mussels, with length above $40 \mathrm{~mm}$ (Sibaja, 1986), were collected manually during periods of low spring tide. The samples were placed in buckets and transported to the Laboratory of Science and Technology in Health of the Federal University of Recôncavo da Bahia (Santo Antônio de Jesus, Bahia), for measurement, weighing, and histological processing. On each sampling occasion, water temperature and salinity were measured in situ, with the assistance of a multiparameter Water Quality Meter AK88 $\left(\mathrm{Akso}^{\circledR}\right)(\mathrm{N}=12)$. Accumulated rainfall over the last 30 days, in $\mathrm{mm}$, were obtained from the National Institute for Space Research (INPE, 2014) for each sampling occasion. Identification of the tidal stage was made consulting the Brazilian Navy Tide Table of the Directorate of Hydrography and Navigation (Brasil, 2015).

The specimens were measured for shell length (anterior-posterior axis), with the usage of a Vernier calliper with a precision of $0.01 \mathrm{~mm}$ and weighed with a precision of $0.001 \mathrm{~g}$, and afterwards were opened and examined macroscopically for colour and gonad texture, as well as for the identification of macroscopic parasites or signs of disease. Immediately afterwards, specimens were fixed in Davidson's solution (Shaw and Battle, 1957). After a 24-hour period, the specimens were transferred to ethanol $70 \%$, processed according to classic histological technique, with dehydration in a series of increasing alcohol concentrations, diafanization in xylene and embedding in paraffin. Thin-sections of $5 \mu \mathrm{m}$ were stained with Harris's haematoxylin and eosin (H\&E), followed by the preparation of slides. The histological cuts were examined using an optical microscope (Leica DM 500 ${ }^{\circledR}$ ), through which sex and the gonadal maturation stages were determined, based on previous studies (Araújo, 2001; Carpes-Paternoster, 2003; Gomes et al., 2009; Luz and Boehs, 2011). Representative phases of each stage of the reproductive cycle were photographed with a camera attached to the microscope.

Temporal variation in the sex ratio was estimated by the absolute frequency of male and female mussels, verifying the hypothesis of a difference in sex ratio from 1:1 across time through the application of the $\chi^{2}$ test. The Kruskal-Wallis test was used to indicate possible differences in gamete release during the period of this study (significance limit: $\alpha=0.05$ ). The Kolmogorov-Sminornoff test was used to verify the normality of the environmental data distribution (water 
temperature and salinity, and rainfall), and the Spearman coefficient was used to establish possible correlations between gamete release and water temperature and salinity, and rainfall. All statistical analyses were carried out using the software SPSS v. 17. All the mussels sampled in this study were collected under licence according to the current legislation (ICMBio- 42081-1).

\section{Results}

\subsection{Environmental data}

The average water temperature was $29.7^{\circ} \mathrm{C}( \pm 2.45 \mathrm{SD})$, with the highest temperature $\left(33.6^{\circ} \mathrm{C}\right)$ in February 2015 and the lowest $\left(25.5^{\circ} \mathrm{C}\right)$ in April 2014 (Figure 1).
The average salinity was 27.2 PSU (Practical Salinity Unit) ( $\pm 3.55 \mathrm{SD})$. The lowest value (21.1 PSU) was registered in August 2014 and the highest (34.4 PSU) in November 2014 (Figure 2). The average rainfall was $101.17 \mathrm{~mm}$, with the lowest values in November $(37.1 \mathrm{~mm})$ and December $2014(48.3 \mathrm{~mm})$ and the highest in June $(159.26 \mathrm{~mm})$ and August 2014 (209.03 mm) (Figure 3). The low salinity in August coincided with the rainiest month in this period, as the highest salinity (November 2014) coincided with the driest period.

\subsection{Morphometry}

The specimens measured between 41.1 and $68.6 \mathrm{~mm}$ (average $=50.64 \mathrm{~mm} \pm 4.98 \mathrm{SD}, \mathrm{n}=363$ ). The macroscopic analyses showed evidence of sexual dimorphism, with
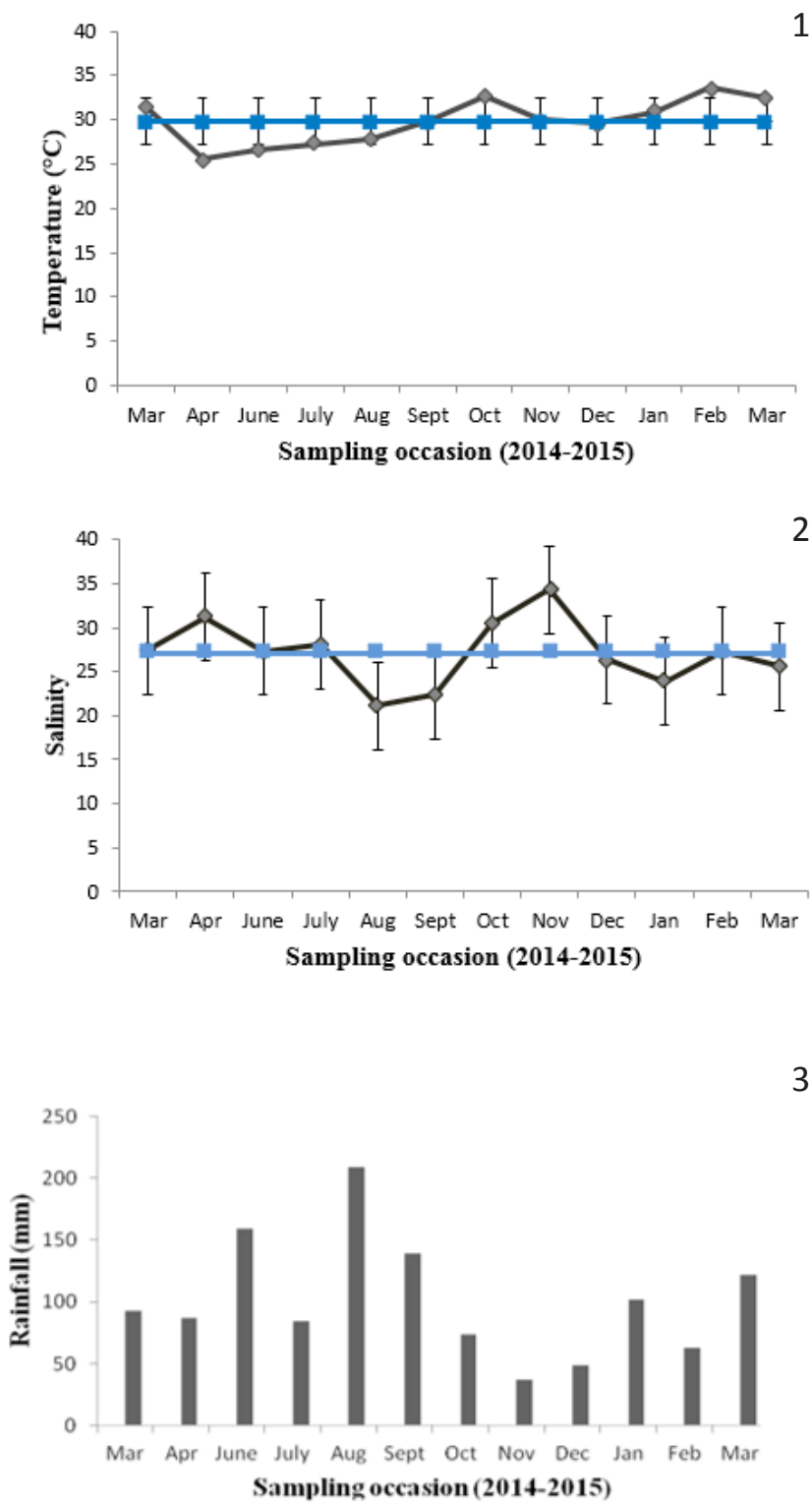

Figures 1-3. Values of temperature $\left({ }^{\circ} \mathrm{C}\right)$, water salinity (PSU) and rainfall level from the collection area of the bivalve Mytella guyanensis, from March 2014 to March 2015. 
the male gonad presenting a milky-white colour and the female gonad an orange colour. The percentage of males (M) was $47.93 \%$ and the females (F) was $49.31 \%$, resulting in a sex ratio $(\mathrm{M}: \mathrm{F})$ of $1: 1(\chi 2=16,757 ; \mathrm{p}>0.05)$. The month in which the greatest variation of the sex ratio occurred was November 2014 (Table 1). Six cases of hermaphroditism (1.1\%) were observed in March, July, and October 2014 (Figure 4). Sex was not determined in six animals (1.65\%) due to parasitic castration by a digenetic trematode (Table 1).

Histological analysis allowed concluding that the reproductive cycle of $M$. guyanensis in the Marine Reserve Bay of Iguape occurred continuously across the year, without a well-defined rest period. Peak numbers of females with full gametes occurred in March, October, and December 2014, and in January and March 2015. Partial release with

Table 1. Absolute frequency of males (M), females (F), of hermaphroditism (H) and parasitic castration (C) in samples of Mytella guyanensis collected in the RESEX Bay of Iguape, Bahia, between March 2014 and March 2015, and results of Chi-square $\left(\chi^{2}\right)$, where $*=\alpha>0.05(\mathrm{n}=363)$.

\begin{tabular}{|c|c|c|c|c|c|c|}
\hline Month & M & $\mathbf{F}$ & $\chi^{2}$ & $\mathbf{H}$ & $\mathrm{C}$ & Total \\
\hline March & 18 & 12 & 1.20 & 2 & 0 & 32 \\
\hline April & 19 & 13 & 1.12 & 0 & 0 & 32 \\
\hline June & 17 & 13 & 0.53 & 0 & 0 & 30 \\
\hline July & 16 & 11 & 0.92 & 1 & 2 & 30 \\
\hline August & 18 & 12 & 1.20 & 0 & 0 & 30 \\
\hline September & 10 & 17 & 1.81 & 0 & 2 & 29 \\
\hline October & 12 & 17 & 0.86 & 1 & 0 & 30 \\
\hline November & 08 & 22 & $6.53 *$ & 0 & 0 & 30 \\
\hline December & 12 & 18 & 1.20 & 0 & 0 & 30 \\
\hline January & 17 & 12 & 0.86 & 0 & 1 & 30 \\
\hline February & 14 & 15 & 0.03 & 0 & 1 & 30 \\
\hline March & 13 & 17 & 0.53 & 0 & 0 & 30 \\
\hline Total & 174 & 179 & 16.75 & 4 & 6 & 363 \\
\hline
\end{tabular}

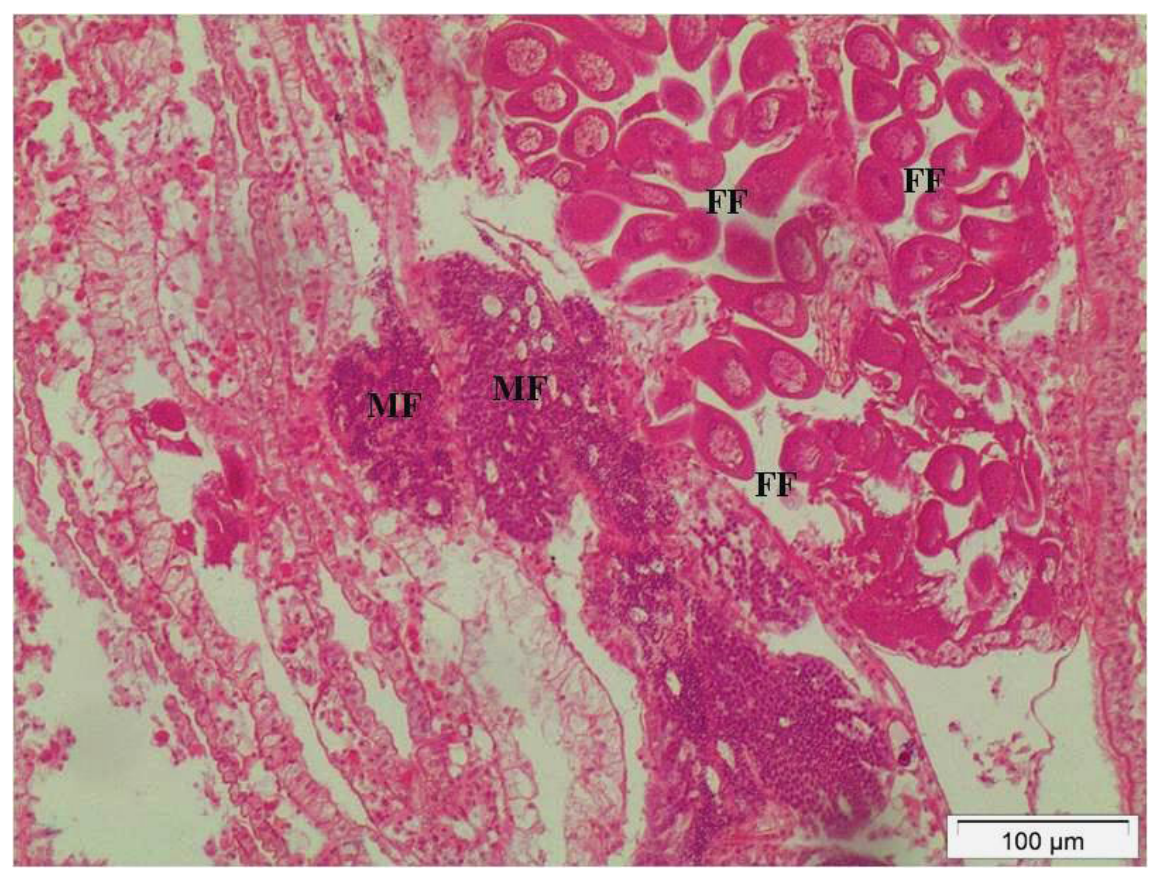

Figure 4. Hermaphroditism in Mytella guyanensis from the Marine Reserve in the Bay of Iguape, Bahia, Brazil. In the central region, the presence of male follicles (MF) containing cells of male germ line and adjacent to these female follicles (FF) containing oogonia and oocytes. Bar: $100 \mu \mathrm{m}$. Staining: H.E. 
gamete proliferation occurred in almost every month for females especially between April and September 2014, and except for March 2015 (Figure 5), and for males the peaks occurred in March, April, July, August, October, and December 2014 and March 2015 (Figure 6). Follicles containing oocytes in lysis were visualized in females with gamete repletion. The period of total release for males and females did not coincide (Figures 5 and 6).

All hermaphrodites presented partial release of gametes. Total release was less prevalent in males than partial release with proliferation (Figure 6). Despite the presence of release peaks of gametes in different times of the year (Figures 5-6), the Kruskal-Wallis test showed that these periods did not differ significantly from rates of release that occurred in other months, both in males $(p=0.576$; $\mathrm{n}=104$,$) and in females (\mathrm{p}=0.161 ; \mathrm{n}=54)$.

At the full gamete stage, the follicles were expanded and juxtaposed for both sexes, presenting mature cells (Figures 7C and 7D; Figures 8C and 8D). On the partial release stage with proliferation, the follicles presented lumens with visible spaces formed by gamete release, both in males and females (Figures 7E and 7F; Figures $8 \mathrm{E}$ and $8 \mathrm{~F}$ ).

The Spearman test indicated no significant correlation between the stages of gamete release and environmental variables: temperature $\left(\mathrm{r}_{\mathrm{s}}=0.004 ; \mathrm{p}=0.958\right)$, salinity $\left(r_{s}=0.010 ; p=0.904\right)$ and precipitation $\left(r_{s}=0.080 ; p=0.310\right)$, considering both males and females together $(n=162)$.
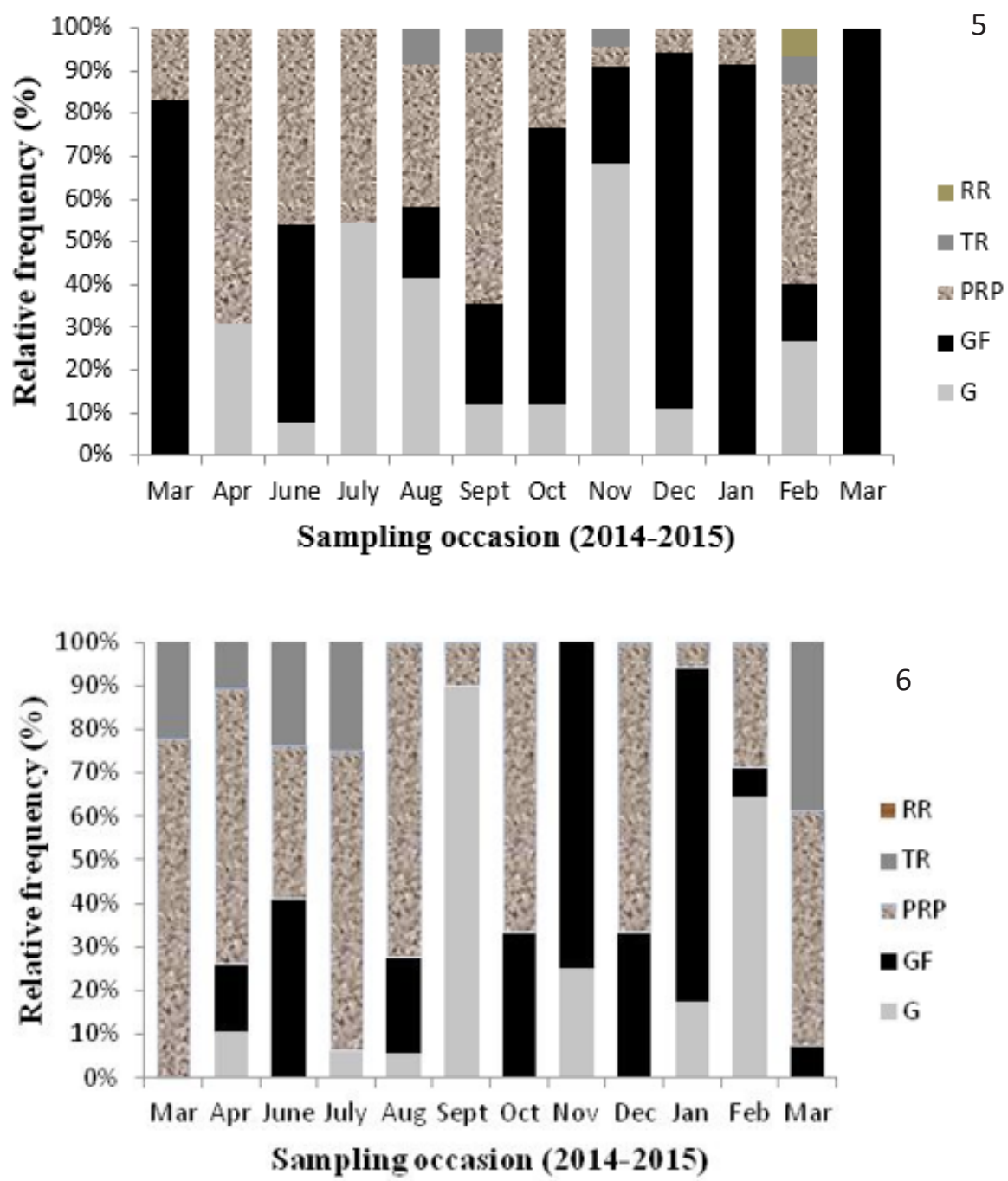

Figures 5-6. Monthly relative frequency of reproductive stages in females (5) and males (6) of Mytella guyanensis from the Marine Reserve Bay of Iguape, Bahia, Brazil, collected between March 2014 and March 2015; (G) Gametogenesis; (GF) Gametes full; (PRP) Partial Release with Proliferation; (TR) Total Release; (RR) Resting. (5) $n=179$ and (6) $n=$ 174. 

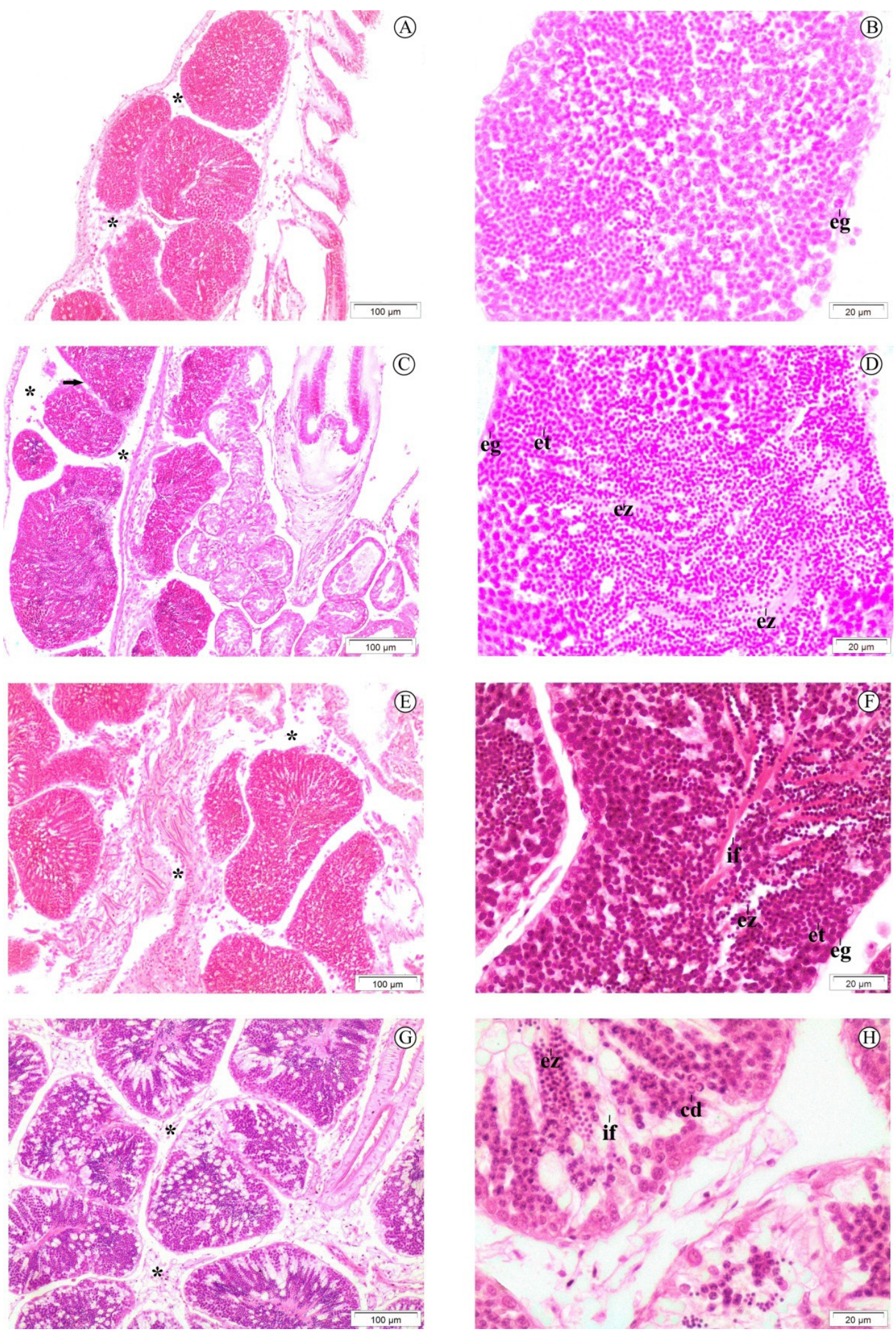

Figure 7. Photomicrographs of Mytella guyanensis gonads in the Marine Reserve Bay of Iguape, Bahia, Brazil. Male at stages of: (A and B) Gametogenesis; (C and D) Repletion of Gametes; (E and F) Partial Release with proliferation and $(\mathrm{G}$ and $\mathrm{H})$ total Release $\mathrm{n}=174$. Label: eg = spermatogonia; et = spermatids; ez = spermatozoon; *interfollicular space, arrows= juxtaposed follicles; if = lumen; $c d=$ misshapen cells. Bar: $100 \mu \mathrm{m}$ and $20 \mu \mathrm{m}$. Staining: HE. 

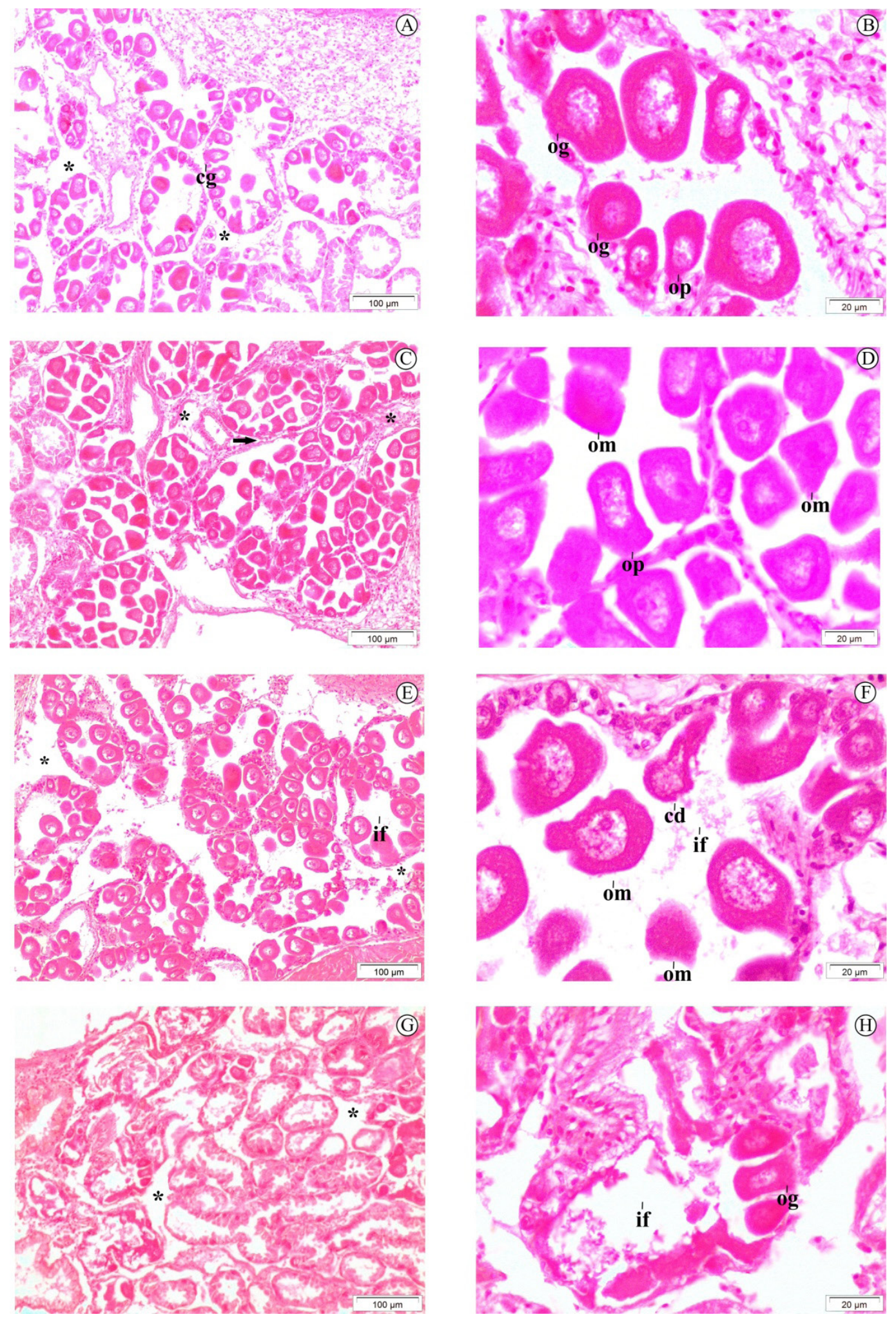

Figure 8. Photomicrographs of Mytella guyanensis gonads in the Marine Reserve Bay of Iguape, Bahia, Brazil. Females at stages of: (A and B) Gametogenesis; (C and D) Repletion of Gametes; (E and F) Partial Release with proliferation and $(\mathrm{G}$ and $\mathrm{H})$ total Release $\mathrm{n}=179$. Label: $\mathrm{og}=$ oogonia; $\mathrm{op}=$ oocyte vitellogenic; om = mature oocyte; *interfollicular space, arrows $=$ juxtaposed follicles; if = lumen; $c d=$ misshapen cells; $\mathrm{cg}=$ germinal layer. Bar: $100 \mu \mathrm{m}$ and $20 \mu \mathrm{m}$. Staining: HE. 


\section{Discussion}

Mytella guyanensis presented sexual dimorphism, related to the colour of the gonads between the sexes in the Caribbean region, as reported by Cruz and Villalobos (1993). However, this fact was not observed in other locations (Carpes-Paternoster, 2003; Luz, 2009; Gomes et al., 2009). Though separate sexes (dioecism) is the dominant situation for mytilids (Coe, 1943), cases of hermaphroditism were reported in the literature on surveys conducted for this species in other Brazilian coastal regions (CarpesPaternoster, 2003; Gomes et al., 2009), which agrees with the findings of this study, and which may be associated with environmental factors, such as sudden variation in salinity and pollution (Ceuta et al., 2010).

As for the sex ratio, the ratio of male to female of $M$. guyanensis did not differ from 1:1, corroborating with affirmations of Coe (1943) for marine bivalves, and was similar to that found in other locations, such as in the Ochoa estuary, Costa Rica (Cruz and Villalobos, 1993); in Tavares River, Santa Catarina Island (Carpes-Paternoster, 2003); in Cachoeira River, Ilhéus, Bahia (Luz, 2009) and in the Caeté estuary, Bragança, Pará (Gomes et al., 2009). Significant differences were found in the sex ratio for this species in a study made by Adorno (2003), in Oruabo Farm, Bahia's Recôncavo, with male predominance. However, the method used by this author (macroscopic observation followed by puncture and fresh analysis of gonadal material), in agreement with what was observed by Cruz and Villalobos (1993), is not very reliable, as sexual dimorphism is not always so evident in this species (Gomes et al., 2009).

Various studies (Loosanoff and Davis, 1952; Galtsoff, 1964; Grotta and Lunetta, 1980) showed that abiotic factors (mainly temperature and salinity) control gametogenesis, because they influence transfer mechanisms of stored reserves in the digestive gland to the gonads, in addition to determining the qualitative and quantitative composition of the plankton, which is the mussels' food, supply the nutritive demand for these animals. High temperatures stimulate gametogenesis, promoting maturation of the gonads and gametes proliferation and spawning, whereas low temperatures usually inhibit the initial process of maturation (Gil and Thomé, 2004). Based on this, the high and stable temperatures throughout the year in the region of study favoured the continuous reproductive cycle. According to Boehs (2000), bivalves of tropical regions, where the seasons are well defined, tend to present continuous reproduction, with peaks of gamete release. This was observed for M. guyanensis in Brazil's North (Gomes et al., 2009) and Northeast (Luz, 2009) regions, as well as for other bivalve species, such as Anomalocardia brasiliana (Lavander et al., 2011), Crassostrea rhizophorae (Lenz and Boehs, 2011), Tagelus plebeius (Ceuta and Boehs, 2012), Perna viridis (Acosta et al., 2012), and Iphigenia brasiliana (Silva et al., 2012).

Regarding salinity, Leonel et al. (1983), in a study of variation in salinity, showed experimentally that $A$. brasiliana resisted salinity variations ranging from 17 to 42 , with optimal value of 22 , values in the range found in this study. Near the limits of tolerance, bivalves close the valves, reducing the filtering and feeding rate, which affects gametogenesis. For M. guyanensis in the region of study, there was no significant correlation between the gamete release and rainfall, which preponderantly determines the salinity levels.

Most intense peaks of partial release with proliferation were less frequent in females than in males, and the same occurred regarding the duration of the period, a result that coincides with the ones found by Mzighani (2005) for Anadara antiquare, with females proliferating more slowly than males. Oogenesis is, in general, a slower process than spermatogenesis and requires higher energy expenditure, since the female gametes usually need to accumulate reserves for the first stages of embryo development, and that is why they tend to be substantially bigger compared to the male gametes (Gosling, 2003).

Continuous reproduction of $M$. guyanensis in the Marine Reserve Bay of Iguape promotes constant renovation of the population, allowing, at first, the exploration of this species throughout the year. Therefore, a management plan is necessary to assure the conservation of the mussel beds in the region and the sustainable exploitation of this food resource. This plan should include the creation of a closed season during the months with high release of gametes (March, April, July and August) and restrictions regarding the harvesting of small M. guyanensis throughout the year.

In agreement with Morgan (2008) on the importance of studies regarding reproduction for species conservation, the results of the present study may subsidize a regulation plan of the intensity of use of $M$. guyanensis in the RESEX Bay of Iguape in order to reduce the anthropogenic impacts on this food resource in this reserve.

\section{Acknowledgements}

The authors thank the Fundação de Amparo à Pesquisa do Estado da Bahia (FAPESB) for financing the project (TSC0021/2012), the Gonçalo Muniz/Fiocruz laboratory for the preparation of slides, and the "marisqueiras" from the community Engenho da Ponte for helping with the collection of biological material.

\section{References}

ADORNO, E.V., 2003. Estudo populacional de Mytella guyanensis (Lamarck, 1819) (Bivalvia-Mytilidae) em manguezais do Recôncavo Baiano: uma análise comparativa. Salvador: Instituto de Biologia da Universidade Federal da Bahia, 112 p. Master's Thesis.

ARAÚJO, C.M., 2001. Biologia Reprodutiva do berbigão Anomalocardia brasiliana (Gmelin, 1791) (Mollusca, Bivalvia, Veneridae) na Reserva Extrativista Marinha de Pirajubaé. São Paulo: Instituto de Biociências da Universidade de São Paulo, 204 p. PhD Thesis.

BOEHS, G., 2000. Ecologia populacional, reprodução e contribuição em biomassa de Anomalocardia brasiliana (Gmelin, 1791) (Bivalvia: Veneridae) na Baía de Paranaguá, Paraná, Brasil. Curitiba: Universidade Federal do Paraná, 200 p. Tese de Doutorado em Zoologia. 
BRASIL. Ministério do Meio Ambiente - MMA, 2000. Lei $n^{\circ}$ 9.985, de 18 de julho de 2000. Regulamenta o art. 225, par. $1^{\circ}$, incisos I, II, III e VII da Constituição Federal, institui o sistema nacional de unidades de conservação da natureza e dá outras providências. Diário Oficial da República Federativa do Brasil, Brasília, 19 jul., pp. 1.

BRASIL. Marinha do Brasil, 2015 [Viewed 5 November 2015]. Previsões de marés [online]. Available from: http://www.mar. mil.br/dhn/chm/box-previsao-mare/tabuas/.

CARPES-PATERNOSTER, S., 2003. Ciclo reprodutivo do mariscodo-mangue Mytella guyanensis (Lamarck, 1819) no manguezal do Rio Tavares - Ilha de Santa Catarina/SC. Florianópolis: Universidade Federal de Santa Catarina, 30 p. Master's Thesis.

CARRANZA, A., DEFEO, O., BECK, M. and CASTILLA, J.C., 2009. Linking fisheries management and conservation in bioengineering species: the case of South American mussels (Mytilidae). Reviews in Fish Biology and Fisheries, vol. 19, no. 3, pp. 349-366. http://dx.doi.org/10.1007/s11160-009-9108-3.

CEUTA, L.O. and BOEHS, G., 2012. Reproductive cycle of Tagelus plebeius (Mollusca: Bivalvia) in the estuary of the Cachoeira River, Ilhéus, Bahia, Brazil. Brazilian Journal of Biology $=$ Revista Brasileira de Biologia, vol. 72, no. 3, pp. 569-576. PMid:22990828. http://dx.doi.org/10.1590/S151969842012000300020 .

CEUTA, L.O., BOEHS, G. and SANTOS, J.J.B., 2010. Hermaphroditism among dioecious Tagelus plebeius (Lightfoot, 1786) (Mollusca, Psammobiidae) and Iphigenia brasiliana (Lamarck, 1818) (Mollusca, Donacidae) on the Cachoeira River Estuary, Ilhéus, Bahia, Brazil. Brazilian Journal of Biology $=$ Revista Brasileira de Biologia, vol. 70, no. 1, pp. 125-127. PMid:20231968. http:// dx.doi.org/10.1590/S1519-69842010000100017.

CHRISTO, S.W. and ABSHER, T.M., 2001. Ciclo Reprodutivo de Mytella guyanensis e Mytella charruana (Bivalvia: Mitilidae), na Baía de Paranaguá, Paraná. In: IX Congreso Latinoamericano sobre Ciencias del Mar, 16-20 Setembro 2001, San Andrés Isla, Colombia. Bogotá: Editorial Universidad Nacional de Colombia.

COE, W.R., 1943. Sexual differentiation in mollusks I. Pelecypods. The Quarterly Review of Biology, vol. 18, no. 2, pp. 154-164. http://dx.doi.org/10.1086/394673.

CRUZ, R.A. and VILLALOBOS, C.R., 1993. Shell lenght at sexual maturity and spawing cycle of Mytella guyanensis (BivalviaMytilidae) from Costa Rica. Revista de Biología Tropical, vol. 41, no. 1, pp. 89-92.

GALTSOFF, P.S., 1964. The American oyster Crassostrea virginica (Gmelin). U.S. Fish and Wildlife Service Fishery Bulletin, vol. 64, pp. 1-457.

GARNER, J.T., HAGGERTY, T.M. and MODLIN, R.F., 1999. Reproductive cycle of Quadrula metanevra (Bivalvia:Unionidae) in the Pickwick Dam Tailwater of the Tennessee River. American Midland Naturalist, vol. 141, no. 2, pp. 277-283. http://dx.doi. org/10.1674/0003-0031(1999)141[0277:RCOQMB]2.0.CO;2.

GIL, G.M. and THOMÉ, J.W., 2004. Descrição do ciclo reprodutivo de Donax hanleyanus (Bivalvia,Donacidae) no sul do Brasil. Iheringia, vol. 94, no. 3, pp. 271-276. http://dx.doi.org/10.1590/ S0073-47212004000300008.

GOMES, P.C., BEASLEY, C.R., PEROTE, S.M.O., FAVACHO, A.S., SILVA, L.S., TAGLIARO, C.H., FERREIRA, M.A.P. and ROCHA, R.M., 2009. Gametogenesis in the mangrove mussel Mytella guyanensis from northern Brazil. Pan-American Journal of Aquatic Sciences, vol. 4, no. 2, pp. 247-250.
GOSLING, E., 2003. Bivalve molluscs: biology, ecology and culture. Oxford: Fishing New Books, Blackwell Scientific Publications. 443 p.

GROTTA, M. and LUNETTA, J.E., 1980. Ciclo Sexual de Anomalocardia brasiliana (Gmelin, 1791) do Litoral do Estado da Paraíba. Revista Nordestina de Biologia, vol. 1, no. 3, pp. 5-55.

GROTTA, M., 1993. Ciclo sexual de Mytella guyanensis (Lamarck, 1819) (Bivalvia - mytilidae), do estuário do Rio Paraíba do Norte. Revista Nordestina de Zoologia, vol. 1, no. 1, p. 70.

INSTITUTO NACIONAL DE PESQUISAS ESPACIAIS - INPE, 2014 [viewed 10 January 2016]. Programa de Monitoramento Climático em Tempo Real da Região Nordeste [online]. Available from: http://proclima.cptec.inpe.br/balanco_hidrico/balancohidrico. $\operatorname{shtml} /$.

LAVANDER, H.D., OLIVEIRA, L.C., OLIVEIRA, R.M., SILVA NETO, S.R., GALVEZ, A.O. and PEIXOTO, S.R.M., 2011. Biologia reprodutiva da Anomalocardia brasiliana (Gmelin, 1791) no litoral norte de Pernambuco, Brasil. Revista Brasileira de Ciências Agrárias, vol. 6, no. 2, pp. 344-350. http://dx.doi. org/10.5039/agraria.v6i2a1139.

LENZ, T. and BOEHS, G., 2011. Ciclo reproductivo del ostión de manglar Crassostrea rhizophorae (Bivalvia: Ostreidade) en la Bahía de Camamu, Bahia, Brasil. Revista de Biología Tropical, vol. 59, no. 1, pp. 137-149. PMid:21516642.

LEONEL, R.M.V., MAGALHÃES, A.R.M. and LUNETTA, J.E., 1983. Sobrevivência de Anomalocardia brasiliana (Gmelin,1791) (Mollusca: Bivalvia), em diferentes salinidades. Boletim de Fisiologia Animal, vol. 7, pp. 63-72.

LOOSANOFF, V.L. and DAVIS, H.C., 1952. Temperature requirements for maturation of gonads of northern oysters. The Biological Bulletin, vol. 103, no. 1, pp. 80-96. http://dx.doi. org/10.2307/1538408.

LUZ, J.R. and BOEHS, G., 2011. Reproductive cycle of Anomalocardia brasiliana (Mollusca: Bivalvia: Veneridae) in the estuary of the Cachoeira River, Ilhéus, Bahia. Brazilian Journal of Biology $=$ Revista Brasileira de Biologia, vol. 71, no. 3 , pp. $679-686$

LUZ, J.R., 2009. Ciclo reprodutivo de moluscos bivalves de interesse econômico do Estuário do Rio Cachoeira, Ilhéus, Bahia. Bahia: Universidade Estadual de Santa Cruz, 47 p. Master's Thesis.

MORGAN, M.J., 2008. Integrating reproductive biology into scientific advice for fisheries Management. Journal of Northwest Atlantic Fishery Science, vol. 41, pp. 37-51. http://dx.doi. org/10.2960/J.v41.m615.

MZIGHANI, S., 2005. Fecundity and populations structure of cockles, Anadara antiquate L.1758 (Bivalvia: Arcidae) from a sandy/muddy beach near Dar es Salaam, Tanzania. Western Indian Ocean Journal of Marine Science, vol. 4, no. 1, pp. 77-84. http:// dx.doi.org/10.4314/wiojms.v4i1.28475.

NISHIDA, A.K. and LEONEL, R.M.V., 1995. Occurrence, population dynamics and habitat characterization of Mytella guyanensis (LAMARCK, 1819) (Mollusca, Bivalvia) in the Paraiba do Norte river estuary. Boletim do Instituto de Oceanografia, vol. 43, no. 1, pp. 41-49.

PINTO, T.R. and BOEHS, G., 2008. Nematopsis sp. (Apicomplexa: Eugregarinida) em Mytella guyanensis (Lamarck, 1819) (Bivalvia: Mytilidae) da Região Estuarina do Rio Cachoeira, Ilhéus, Bahia, Brasil. Brazilian Journal of Veterinary Research and Animal Science, vol. 45, no. 2, pp. 95-100. 
PROST, C., 2010. Resex Marinha versus polo naval na Baía do Iguape. Novos Cadernos NAEA, vol. 13, no. 1, pp. 47-70. http:// dx.doi.org/10.5801/ncn.v13i1.391.

RIOS, E.C., 1994. Seashells of Brazil. 2nd ed. Rio Grande: Fundação Universidade do Rio Grande. 330 p.

RIOS, E.C., 2009. Compendium of Brazilian Sea shells. Rio Grande: Evangraf. 668 p.

SANTOS, T.M.M., SAWAYA, A.L., SILVA, M.C.D., SANTOS, A.F., BARROS NETO, J.A. and FLORÊNCIO, T.M.M.T., 2014. Avaliação microbiológica e da concentração de vitamina A, ferro e zinco em preparações do molusco sururu (Mytella falcata). Demetra: Alimentação, Nutrição \& Saúde, vol. 9, no. 3, pp. 811822. http://dx.doi.org/10.12957/demetra.2014.9440.
SHAW, B.L. and BATTLE, H.I., 1957. The gross and microscopic anatomy of the digestive tract of the oyster Crassostrea virginica (Gmelin). Canadian Journal of Zoology, vol. 35, no. 3, pp. 325347. http://dx.doi.org/10.1139/z57-026.

SIBAJA, W.J., 1986. Madurez sexual en el mejillon chora Mytella guyanensis (LAMARCK, 1819) (Mollusca, Bivalvia) del manglar en Jicaral, Puntarenas, Costa Rica. Revista de Biología Tropical, vol. 34 , no. 2, pp. 151-155.

SILVA, P.P., PESO-AGUIAR, M.C. and RIBEIRO, G., 2012. Ciclo gametogênico e comportamento reprodutivo de Iphigenia brasiliana (Mollusca, Bivalvia, Donacidae) noestuário do Rio Subaé, Baía de Todos os Santos, Bahia, Brasil. Iheringia, vol. 102, no. 4, pp. 359-369. http://dx.doi.org/10.1590/S0073-47212012005000011. 